\title{
TRANSFORMATION FOR SUSTAINABILITY AND ITS PROMOTING ELEMENTS IN EDUCATIONAL INSTITUTIONS: A CASE STUDY IN AN INSTITUTION FOCUSED ON TRANSFORMATIVE LEARNING
}

\author{
Transformação para a sustentabilidade e seus elementos promotores \\ nas instituições de ensino: um estudo de caso em uma \\ instituição focada na aprendizagem transformadora
}

Lisiane Celia Palma*

Eugênio Ávila Pedrozo**

\begin{abstract}
This paper aims to identify what changes are necessary in educational institutions (Els) to improve their potential as promoters of transformation for sustainability. Thus, a case study was conducted in an El, in England, which seeks to promote transformative learning for sustainable living. Data were obtained through 8 interviews, analysis of 12 documents, and observations carried out in February and March 2014. Using the Sustainable Transformative Learning Framework and the elements that promoted the transformation to sustainability in Els found in the literature as references, the case study was analyzed focusing on the processes of change for sustainability, management, and teaching-learning. Two of the main findings are: the adoption by the El of sustainable strategies and objectives that go beyond the Triple Bottom Line, involving multiple stakeholders; broadening of the teaching-learning process going beyond cognitive objectives, adopting a strategy of sustainable education and transdisciplinarity.
\end{abstract}

Keywords: Sustainability; Transformative Learning; Teaching-Learning Process; Organizational Change.

\section{RESUMO}

Este artigo tem como objetivo identificar quais são os elementos promotores da transformação para a sustentabilidade nas instituições de ensino (IEs). Para tanto, foi realizado um estudo de caso em uma IE, localizada na Inglaterra, que busca promover a aprendizagem transformadora para uma vida sustentável. Os dados foram obtidos por meio de 8 entrevistas em profundidade, análise de 12 documentos e observações em visitas realizadas na IE nos meses de fevereiro e março de 2014. Utilizando-se como referências o Framework da Aprendizagem Transformadora Sustentável e os elementos promotores da transformação para a sustentabilidade nas IEs encontrados na literatura, procedeu-se a análise do estudo de caso com foco nos processos de mudança para a sustentabilidade, gestão e ensino-aprendizagem. Dentre os principais elementos encontrados têm-se: a adoção, pela IE, de estratégias sustentáveis e de objetivos que vão além do Triple Botton Line, envolvendo múltiplos atores; a ampliação do enfoque do processo de ensino-aprendizagem para além dos objetivos cognitivos, adotando a educação sustentável e a transdiciplinaridade.

Palavras-chave: Sustentabilidade; Aprendizagem Transformadora; Ensino-Aprendizagem; Mudança Organizacional.

\footnotetext{
* Professor at the Federal Institute of Education, Science and Technology of Rio Grande do Sul (IFRS). Holds a PhD in Business Administration from the Federal University of Rio Grande do Sul (UFRGS). Email: lisiane. palma@canoas.ifrs.edu.br. ORCID: 0000-0001-6419-0622

** Professor at the Graduate Program in Business Administration at the Federal University of Rio Grande do Sul (PPGA/EA/UFRGS). Holds a PhD in Industrial Engineering from the Institut National Polytechnique of Lorraine (INPL), France. Email: eugenio.pedrozo@ufrgs.br. ORCID:0000-0002-4751-707X
} 


\section{INTRODUCTION}

$\mathrm{M}$ uch has been discussed regarding socio-environmental problems and the role of universities in this area (e.g. STERLING, 2011; LOZANO, 2008; FERRER-BALAS; BUCKLAND; MINGO, 2009). Nevertheless, the contributions of such organizations to sustainability still appear scarce, considering their potential as promoters of reflection and innovation.

This discussion is particularly important with regard to the Business Schools (BSs), which play a key role in the training of managers. These will be leading the organizations in the near future, being responsible for the insertion or exclusion of aspects related to sustainability. As such, BSs should be aware of this discussion, as they better prepare future decision makers for changes towards sustainability.

Some studies have already shown that a concern for the issue of sustainability has been verified in Business Administration courses and has led to changes (e.g. DEMAJOROVIC; SILVA, 2012; BRUNSTEIN; GODOY; SILVA, 2014; PALMA, NASCIMENTO; ALVES, 2017). According to Brunstein, Godoy and Silva (2014, p. 2), "[...] we have witnessed the strengthening of academic reflection and practical educational experiences for sustainability in classrooms and business courses, which gradually grow in quantity and density." Notwithstanding, it should be noted that, although there is an ongoing movement in higher education schools worldwide, there is still "[...] the need to build more robust educational actions to train a new generation of administrators that are prepared to respond to the demands of a sustainable logic" (CARVALHO; BRUNSTEIN; GODOY, 2014, p. 114).

Several factors contribute to this. One of them is that many proposals do not consider sustainability to be a complex issue, involving multiplayers (politicians, entrepreneurs, environmentalists, academics, etc.), multiple factors (economic, social, environmental, cultural, etc.), multilevel effects (micro, meso, and macro) and, consequently, requires multiple references to be examined, thus, by means of a systemic and inter/transdisciplinary view (WALS; SCHWARZIN, 2012; MÜLLER-CHRIST et al., 2013).

Nevertheless, the conceptual framework of the neoclassical theory and the paradigm of simplification (MORIN, 2011), which prevail in our society and explicitly in the BSs, have led to a limited understanding of the human being (SODERBAUM, 1999; MURTAZA, 2011) and organizations (STUBBS; COCKLIN, 2008; SODERBAUM, 2009), and, consequently, sustainability. This has mainly resulted in the development of fragmented proposals and marginal changes in individuals, organizations, and society.

In the field of Business Administration, teaching has presented a bias in the concept implicit in the practice of normal science, focusing on "[...] diagnosing the causes of inefficiency within organizations and prescribing how they can become more efficient by ascertaining the underlying conditions through which goals are promoted or hampered" (MARSDEN; TOWNLEY, 2001, p. 42). Thus, a normal organizational science based on "a theory about the management and for the management" was reflected on and addressed, the managers acting as "guardians of the rationality, interpreting market signals for the good of all" (MARSDEN; TOWNLEY, 2001, p. 42). 
According to Serva, Dias and Alperstedt (2010), orthodoxy in the theory of organizations was developed based on metaphors supported by the functionalist paradigm, engendering the development of theories based on fundamentals that were little questioned until the 1980s. To the extent that these assumptions are reinforced and continually reaffirmed, this orthodox view of the world is assumed to be unique and unquestionable. Thus, the thousands of students attending business schools, and even executives who have never attended them, are immersed in this logic, grounded on theories and approaches that propagate the ideal of the market and which advocate little to no sense of responsibility (GHOSHAL, 2005). Nevertheless, sustainability requires profound changes. In this sense, some authors argue that, for effective advances to take place towards sustainability, both individuals and organizations should undergo a transformative learning process (e.g. BLAKE; STERLING; GOODSON, 2013; STERLING, 2011; SIPOS; BATTISTI; GRIMM, 2008). Transformative learning, according to Mezirow (1997), refers to the process of bringing about change in a frame of reference. It is related to changes that go beyond behavioral change, posing a challenge to existing beliefs and ideas, and promoting the reconstruction of meanings. It suggests a more radical change, involving a paradigm shift, rather than a modification within the existing paradigm.

In order to contribute to the debate, this article aims to identify the elements that promote this transformation for sustainability in educational institutions (Els). For this purpose, a bibliographic research was carried out, followed by a case study in an El that seeks to promote transformative learning for a sustainable life.

Thus, some elements are initially introduced that promote transformative sustainability learning (TSL), which are found in the literature. Next, the methodological procedures and main analysis and results of the case study are presented, which complement these elements. Finally, some final considerations are made, and the references used in this research are presented.

\section{TRANSFORMATIVE SUSTAINABILITY LEARNING - CONTRIBUTIONS FROM THE LITERATURE}

When addressing the issue of sustainability, it is crucial to consider that there are different interpretations in relation to the subject and the means that are necessary to reach it (HOPWOOD; MELLOR; O'BRIEN, 2005; SODERBAUM, 2009). To help make sense of the existing multiple interpretations of sustainability, Hopwood, Mellor and O'Brien (2005) divide them into three broad views on the nature of the changes required in societal policy, economic structures, and relationships between man and the environment in order to achieve sustainability: 1 ) it can be achieved within present structures - status quo; 2) a fundamental reform is required, but without a complete break with the existing arrangements - reform; and 3 ) as the roots of problems are society's own economic and power structures, a radical transformation is necessary - transformation.

Such interpretations are related to the worldview of individuals, which subsequently influence the characteristics of organizations and the way in which they are conducted. As regards the worldview of individuals, some authors criticize the exclusive focus on the Neoclassical Economic Man (e.g. HELNE; HIRVILAMMI, 2017; BINA; VAZ, 2011; BECKER, 
2006) and present alternative proposals such as Homo sustinens (SIEBENHÜNER, 2000) and Homo ecologicus (BECKER, 2006).

As asserted by Helne and Hirvilammi (2017), living life as Homo economicus implies a limited perspective of the rationality of human life. In this conception, the fundamental meaning of the relations between human beings is lacking: the relation with oneself, the relation with other living beings, present and future; and the relationship with nature. These relationships are extremely important in the context of sustainability.

Bina and Vaz (2011) synthesize the concepts of Homo economicus - which is characterizedthe human as the self-interested utility maximizer (the narrow self) - and alternative proposals - Homo sustinens / politicus / ecologicus: characterized by social learning, moral responsibility and a range of social dimensions of human existence, including altruism and cooperation (the broader self). In order to do so, they present a summary of the main dimensions that shape the different conceptions of the human being in an attempt to compensate for the limitations of the concept of Homo economicus and to correct distortions resulting from the self and what it means to be human. The focus on self-relation and egoistical behaviour (Siebenhüner, 2000) is in conflict with the need to promote altruism and responsibility for others and for future generations, as well as for the environment and the global commons, at the heart of sustainability (ANAND; SEN, 2000). The idea of utility maximizers is also linked to equally narrow conceptions of justice, with an emphasis on property rights and autonomy of action, regarding limited liability in relationships between people, with future generations and with nature - and, therefore, with the notions of distributive justice (BINA; VAZ, 2011).

Organizations, in turn, being composed of such individuals can therefore also be understood in various ways regarding their role in relation to society and nature, influencing the strategies of the organizations. Thus, the choice of competitive strategies - whose main objective is to maximize shareholders' earnings - or sustainable strategies - which embody the idea that organizations, in addition to bringing gains to shareholders, should also take the stakeholders into consideration (BARIN-CRUZ; PEDROZO; ESTIVALETE, 2006; BAUMGARTNER; KORHONEN, 2010) - is linked to concepts and basic assumptions within paradigms that influence behavior and organizational practice. In this sense, Stubbs and Cocklin (2008), based on a review of the literature on corporate sustainability, have developed a sustainability framework that relates basic concepts and assumptions within the paradigms - ecocentric, ecological modernization, and neoclassical. According to the authors, although the many and varied perspectives on sustainability can be placed along a continuum, they can be summarized in these three broad "fields".

According to Stubbs and Cocklin (2008), the economic neoclassical worldview is the dominant paradigm today. Underlying this paradigm is neoclassical economic theory, which focuses on unlimited economic growth through the operation of free markets and increased consumption of goods and services. Proponents of this view believe that the limits to growth are too distant or non-existent. Technology can and will solve all environmental degradation problems by replacing natural capital with man-made capital and the development of new technologies and processes to deal with pollution and waste.

The antithesis of the neoclassical perspective is ecocentrism. Proponents of the ecocentric worldview believe that it is impossible to have infinite growth in a finite environ- 
ment. Ecocentrism promotes the intrinsic value of nature rather than its instrumental value - ecosystems are seen as having intrinsic value independent of human value judgments. The ecocentric perspective is based on concepts of: egalitarianism; decentralized social, economic and political systems; bioregionalism (regions governed by nature, not by legislation); communitarianism; collectivism; and cooperation (STUBBS; COCKLIN, 2008).

In the 1980s and 1990s, ecological modernizers began to challenge the ecocentric view that there was a zero trade-off between economic prosperity and environmental concern. While not promoting the end of growth, advocates of ecological modernization do not believe that growth can continue forever in a finite world. Ecological modernization focuses on improving human well-being and environmental management (while maintaining the integrity and diversity of nonhuman nature), as well as economic prosperity (STUBBS; COCKLIN, 2008).

In relation to what has been discussed, it can be said that the neoclassical view of both individuals (Homo economicus) and organizations (companies that maximize profit and the interests of the shareholders) is predominant, as it agrees with the dominant paradigm (simplification). Nevertheless, if the goal is a real shift towards sustainability, one must move beyond the status quo, seeking transformation. This implies a paradigm shift, which, in this article, is considered as the shift from the simplification paradigm to that of complexity (MORIN, 2011).

Thus, based on the approaches presented thus far and the discussions carried out, we present the Transformative Sustainability Learning Framework (TSLF) - Figure 1 - which shows the different levels of learning and change that individuals and organizations aim to achieve transformative learning / change (PALMA; PEDROZO, 2014). According to the TSLF, the epistemological basis of individuals and organizations influences the shift towards the insertion of sustainability promoted in Els. Such a change is represented along a continuum and may be marginal (aiming at maintaining the status quo), intermediate (promoting reform), or deeper (aiming at transformation).

In TSLF, the "zero sustainability" framework represents mental models in which aspects of sustainability are not considered, meaning a level where there is still no concern for the subject. First-order learning and change, named respectively as shaping (STERLING, 2011) and marginal (WOLLIN, 1999), refer to the stage in which issues related to sustainability begin to emerge, but these are only reflected in actions, not involving the expansion of the mental model. The individual notices changes in the environment, accesses, designs and implements new actions, without, however, changing their mental model. Adjustments or adaptations are then made to keep things stable in light of change - maintenance is sought. This stage can thus be compared to the view of the status quo in relation to sustainability. For individuals, meaning is taken for granted, and changes occur only in behavioral actions, without questioning what lies behind them. In organizations, the goal is to improve the performance of the already established system by replicating the decision-making groups and the established power relationships, confirming the existing rules. Thus, the characteristics of the Homo economicus and the Neoclassical Organization remain. 


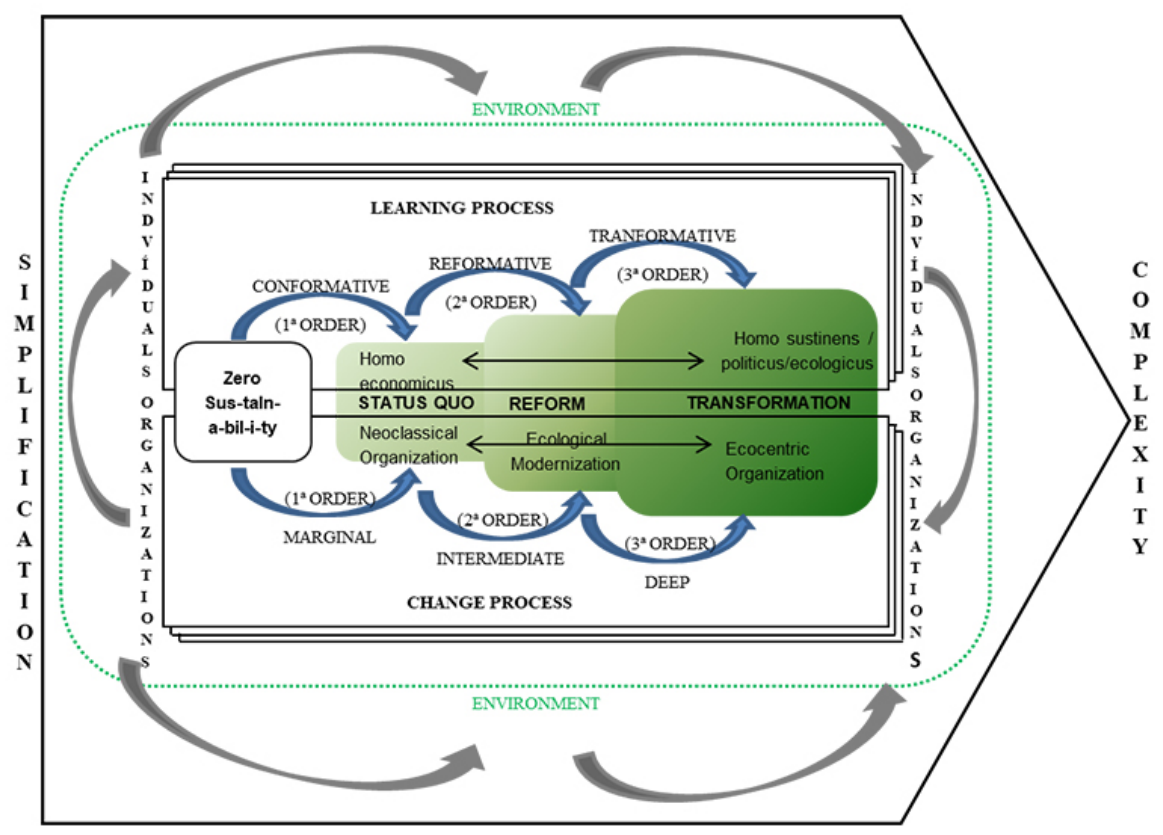

Figure 1 - Transformative Sustainability Learning Framework (TSLF)

Source: Palma and Pedrozo (2014).

Second-order learning, in turn, implies an expansion of mental models and a significant change in the understanding of what is being done as a result of the examination of assumptions and values. In this type of learning, meaning is recognized and negotiated among those involved. Individuals who go through learning at this level - called the reformer (STERLING, 2011) - begin to question the values behind their actions. The organizations that undergo a second-order change (WADDELL, 2007; PRUIT; WADDELL, 2005) - herein referred to as intermediary, as they lie between marginal change and deep change - seek to include concerns about social and environmental issues, as well as economic ones, changing the system to address deficiencies and respond to the needs of stakeholders. It is then understood that a crucial reform is necessary for sustainability, but without a complete break with existing arrangements.

Finally, learning and third-order change - referred to as transformative (STERLING, 2011) and deep (WOLLIN, 1999), respectively - are more radical and imply an even greater expansion of reference frames, meaning a shift in paradigm and meaning, i.e., an effective broadening of the understanding of individuals and organizations. The social role of organizations is then understood, in which not only the goals of shareholders, but also those of stakeholders are considered. Organizations then incorporate ecocentric characteristics. They seek to solve problems proactively and take advantage of opportunities from a system-wide perspective, enabling all participants to be on an equal basis with owners and decision-makers. Questions are opened to completely new ways of thinking, promoting the analysis of the deep structures that underpin the system, thus creating a space for fundamental change. The individual, on the other hand, considers not only their interests (selfish behavior/self-in- 
terest) as a central aspect, but also their responsibility towards others and nature, expanding the reductionist view of the self.

In the framework, the external arrows connecting individuals and organizations reinforce the idea of an existing recursion, in which both influence one another. The environment is also represented and influences, equally in a recursive manner, individuals and organizations. The multiple boxes representing individuals and organizations mean that the same environment contains several individuals and organizations with different mental models (individual and shared, respectively). Therefore, it is important to emphasize the dialogic process as a way of promoting transformation.

Considering the relationships established in the TSLF and the complexity of the issue of sustainability, to enable a qualitative analysis that involves different levels of analysis in an integrated way, the teaching-learning process was elected to be analyzed at the individual level. This is because it is usually led by teachers individually in their classes in Els. This process is influenced by the way the teacher understands the economic stakeholder that may be related to a reduced vision of the human being (Homo economicus) or extended visions (Homo sustinens / politicus / ecologicus). According to the framework, such a vision is supported by foundations ranging from neoclassical to ecocentric. This understanding influences the classroom approach, which may be more instrumental or sustainable.

At the organizational level, the management process is analyzed. Because it is developed in the majority of the Els by the teachers themselves, it is also influenced by the epistemological bases of the individuals that form the organization and, consequently, establish its epistemological foundation. As is the case with the individual level, at the organizational level, the understanding of organizations may be related to the neoclassical vision, ecological modernization, or the ecocentric vision. This will result, respectively, in a management process with a strictly economic (at one end) or sustainable (at the other end) approach.

It is important to emphasize that individuals and organizations, according to the principles of complexity (MORIN, 2011), are considered here recursively, influencing one another. Thus, given that teachers in the majority of the Els exercise the management, the dominant paradigm in the organization, directly related to the individuals that compose it, will have an impact both in management processes and in teaching-learning processes, influencing changes in the organization. The process of change is, therefore, the third process to be analyzed, as emerging from the interaction between individuals and the organization.

Therefore, for Transformative Sustainable Learning (TSL), related to the third level of learning/change, it is important that transformations occur not only in the classroom, but also in the organization as a whole, in order to promote and support sustainable actions. Thus, Table 1 highlights the elements found in the literature (and their respective authors) related to the third level of learning/change - the focus of this study - both in the teaching-learning process and in the process of management and change for sustainability.

These elements are opposed to those traditionally found in Els where, in the teaching-learning process, there is prevalence of the emphasis on cognitive objectives - head (SINGLETON, 2015; SIPOS; BATTISTI; GRIMM, 2008; WALS; JICKLING, 2002); the focus on self-interest and wealth concentration (MURTAZA, 2011); instrumental education / cog- 
nitive learning (PALMA; NASCIMENTO; ALVES, 2017; STERLING, 2011; WALS; JICKLING, 2002; MEZIROW, 1997; FREIRE, 1987); consumer learning with teacher-centered arrangements, individual learning, and theory-dominated learning; and accumulation of knowledge, in content-oriented learning and learning based on institutional staff, without promoting the creation of spaces for alternative paths for development (PALMA, NASCIMENTO; ALVES, 2017; WALS; JICKLING, 2002).

Table 1 - Elements promoting transformations for sustainability in educational institutions found in the literature

\begin{tabular}{|c|c|c|}
\hline TEACHING-LEARNING PROCESS & MANAGEMENT PROCESS & CHANGE PROCESS \\
\hline $\begin{array}{l}\text { - Promotion of a broader vision } \\
\text { of the self and cooperation; } \\
\text { encouraging the consideration of } \\
\text { issues involving the fulfillment of } \\
\text { responsibilities as citizens of the } \\
\text { world; value-focused thinking, } \\
\text { aiming at the promotion of equity } \\
\text { and justice (BINA; VAZ, 2011) }\end{array}$ & $\begin{array}{l}\text { - Design of Ecocentric Organiza- } \\
\text { tions (STUBBS; COCKLIN, 2008) }\end{array}$ & $\begin{array}{l}\text { - Process transformation (WAD- } \\
\text { DELL, 2007; FERRER-BALAS, } \\
\text { BUCKLAND; MINGO, 2009) }\end{array}$ \\
\hline $\begin{array}{l}\text { - Focus on self-realization and } \\
\text { wisdom (MURTAZA, 2011) }\end{array}$ & $\begin{array}{l}\text { - Objectives that go beyond the } \\
\text { Triple Bottom Line, considering } \\
\text { second-order issues (such as } \\
\text { transparency and participation, } \\
\text { reflectivity, integration and equity } \\
\text { between generations). It seeks to } \\
\text { increase quality of life and social } \\
\text { equity - non-human and human } \\
\text { species (STUBBS; COCKLIN, } \\
\text { 2008; STEURER et al., 2005; } \\
\text { KURUCZ; COLBERT; MARCUS, } \\
\text { 2013) }\end{array}$ & $\begin{array}{l}\text { - Proactive problem resolution, } \\
\text { taking advantage of opportunities } \\
\text { from a system-wide perspective } \\
\text { (WADDELL, 2007) }\end{array}$ \\
\hline $\begin{array}{l}\text { - Promoting Sustainability } \\
\text { Education: participatory, } \\
\text { democratic, pluralistic and emanci- } \\
\text { patory (STERLING, 2011; WALS; } \\
\text { JICKLING, 2002) }\end{array}$ & $\begin{array}{l}\text { - Sustainable strategies. Manage- } \\
\text { ment strategy as a social practice } \\
\text { (BARIN-CRUZ, PEDROZO; ESTI- } \\
\text { VALETE, 2006; BAUMGARTNER; } \\
\text { KORHONEN, 2010) }\end{array}$ & $\begin{array}{l}\text { - Changes established in pro- } \\
\text { cesses, structures, culture and/ } \\
\text { or technology (FERRER-BALAS, } \\
\text { BUCKLAND; MINGO, 2009) }\end{array}$ \\
\hline $\begin{array}{l}\text { - Emphasis on cognitive, affective } \\
\text { and related skills goals - head, } \\
\text { hands and heart (SINGLETON, } \\
\text { 2015; SIPOS; BATTISTI; GRIMM, } \\
\text { 2008; WALS \& JICKLING, 2002) }\end{array}$ & $\begin{array}{l}\text { - Organizational commitment to } \\
\text { nature: it aims to educate citizens } \\
\text { for sustainability; it seeks to mi- } \\
\text { nimize the use of virgin materials } \\
\text { and renewable energy; elimination } \\
\text { of emissions and effluents; } \\
\text { non-hierarchical structure; } \\
\text { decentralized authority. (STUBBS; } \\
\text { COCKLIN, 2008). }\end{array}$ & $\begin{array}{l}\text { - Radical change. It is believed that } \\
\text { current environmental and social } \\
\text { challenges require more than a } \\
\text { "modernization" policy (SODER- } \\
\text { BAUM, 2009) }\end{array}$ \\
\hline $\begin{array}{l}\text { - Learning through discovery and } \\
\text { creative resolution of problems; } \\
\text { student-centered arrangements; } \\
\text { collaborative learning; praxis-driven } \\
\text { learning; problem orientation; } \\
\text { self-regulated learning; learning } \\
\text { with and from outsiders (PALMA, } \\
\text { NASCIMENTO; ALVES, 2017; } \\
\text { WALS; JICKLING, 2002) }\end{array}$ & $\begin{array}{l}\text { - It promotes spaces for dialogic } \\
\text { interaction (WALS; SCHWARZIN, } \\
\text { 2012) }\end{array}$ & - Collaboration (LOZANO, 2008) \\
\hline
\end{tabular}




\begin{tabular}{|c|c|c|}
\hline TEACHING-LEARNING PROCESS & MANAGEMENT PROCESS & CHANGE PROCESS \\
\hline \multirow[t]{3}{*}{$\begin{array}{l}\text { - Creation of spaces - space for } \\
\text { alternative paths of development; } \\
\text { space for new ways of thinking, } \\
\text { evaluating and doing; space for } \\
\text { participation; space for pluralism, } \\
\text { diversity and minority perspectives; } \\
\text { space for deep consensus, but also } \\
\text { for respectful dissent; space for } \\
\text { autonomous and deviant thinking; } \\
\text { space for self-determination; space } \\
\text { for contextual and spatial differen- } \\
\text { ces (WALS; JICKLING, 2002) }\end{array}$} & & $\begin{array}{l}\text { - Transdisciplinarity (ROORDA, } \\
\text { 2001) }\end{array}$ \\
\hline & & $\begin{array}{l}\text { - Horizontal integration (SIPOS, } \\
\text { BATTISTI; GRIMM, 2008; CEULE- } \\
\text { MANS; DE PRINS, 2010) }\end{array}$ \\
\hline & & $\begin{array}{l}\text { - It creates a microcosm of the pro- } \\
\text { blem system, with all participants } \\
\text { entering into equal conditions } \\
\text { in the decisions. Top-down and } \\
\text { bottom-up (WADDELL, 2007; } \\
\text { FERRER-BALAS, BUCKLAND; } \\
\text { MINGO, 2009) }\end{array}$ \\
\hline
\end{tabular}

Source: Authors' work.

In terms of the management process, the Els have traditionally presented the increase in revenue/profit as the main objective, with economic aspects predominating with respect to the Triple Bottom Line (TBL) (STUBBS; COCKLIN, 2008; STEURER et al., 2005; KURUCZ; COLBERT; MARCUS, 2013); adoption of competitive strategies, seeking technical efficiency and viewing sustainability as a way to gain competitive advantage (STUBBS; COCKLIN, 2008; BARIN-CRUZ; PEDROZO; ESTIVALETE, 2006; BAUMGARTNER; KORHONEN, 2010); and a competitive hierarchical structure (STUBBS; COCKLIN, 2008), with no room for dialogic interaction (WALS; SCHWARZIN, 2012; WADDELL, 2007).

Consequently, the process of change for sustainability in Els, in general, when it happens, presents the following characteristics: search for the optimization of the existing process and improvement of the performance of the already established system (WADDELL, 2007; FERRER-BALAS; BUCKLAND; MINGO, 2009; SODERBAUM, 2009); focus on coordination (LOZANO, 2008), multi-disciplinarity (ROORDA, 2001), and vertical integration (CEULEMANS; DE PRINS, 2010; SIPOS; BATTISTI; GRIMM, 2008); and replication of decision-making groups and established power relations (top-down), involving only internal stakeholders in the process of change (FERRER-BALAS; BUCKLAND; MINGO, 2009; WADDELL, 2007). That is, there is a focus on marginal change, which results in the maintenance of the status quo, without promoting transformation.

Following the discussions presented, which bring as results the elements that promote the transformation to sustainability in the educational institutions found in the literature, an explanation of the methodological procedures adopted in the accomplishment of the case study is presented. 


\section{METHODOLOGICAL PROCEDURES}

In order to verify, in practice, the existence of the elements that promoted the transformation to sustainability found in the literature (Table 1), a case study was carried out in a course and/or El that proposed to implement Transformative Learning. Thus, a case study was conducted in the "Economics for Transition" course offered by an El (identified in this study as School Z in order to preserve its identity), which seeks to promote "transformative learning for a sustainable life" (SCHOOL Z WEBSITE, 2014).

The choice for this course was based on the fact that it presents some peculiarities, detailed in the following section. It should be noted that the organization in focus is acknowledged internationally for working with transformative learning and sustainability. According to the institutional website, School Z has offered courses for more than 20 years, aiming to promote transformative learning experiences in small groups, and focuses on interactive and participatory learning, offering "[...] practical skills and strategic thinking required to face the ecological, economic and social challenges of the 21 st century [...]."

The research data were obtained by means of 8 in-depth interviews, analysis of 12 documents, and observations in visits to the El in February and March 2014, allowing the triangulation of data (YIN, 2001). The in-depth interviews were conducted in English and were recorded, transcribed and translated into Portuguese. These had an average duration of 44 minutes each. Tables 2 and 3 describe the position of the interviewees and the documents analyzed.

Table 2 - Interviews conducted in Case Z

\begin{tabular}{c|l}
\hline Interview Number & \multicolumn{1}{c}{ Interviewee } \\
\hline 1 & Dean of School Z \\
\hline 2 & $\begin{array}{l}\text { Professor at School Z and co-head of development of the course of Economics } \\
\text { for Transition. Also the manager of School Z's website. }\end{array}$ \\
\hline 3 & Professor of School Z and Coordinator of the Economics for Transition course \\
\hline 4 & $\begin{array}{l}\text { Professor at the Business School at University Y and Professor of the Economics } \\
\text { for Transition course }\end{array}$ \\
\hline 5 & Co-founder of POA and Professor of Economics for Transition \\
\hline 6 & $\begin{array}{l}\text { Director of Finance and Business of POB and Professor of the Economics for } \\
\text { Transition course }\end{array}$ \\
\hline 8 & $\begin{array}{l}\text { Professor at University Y; former student of School Z and Professor of Economics } \\
\text { for Transition }\end{array}$ \\
\hline & Volunteer at School Z \\
\hline
\end{tabular}

Source: Authors' work.

The analysis was based on the elements highlighted in Table 1. The teaching-learning processes, evolution of management, and change for sustainability were analyzed, aiming to include the individual, organizational and learning/change levels presented in the TSLF. For each of these levels, the aim was to identify the existence or non-existence of the 
elements promoting the transformation to sustainability in educational institutions found in the literature. The main results and analyses are presented in the following section.

Table 3 - Documents analyzed in Case Z

\begin{tabular}{c|l}
\hline Document Number & \multicolumn{1}{c}{ Description } \\
\hline 1 & Economics for Transition Course Program Specification \\
\hline 2 & Course Approval Document \\
\hline 3 & Student Handbook \\
\hline 4 & Institutional Website of School Z \\
\hline 5 & Institutional Website of University Y \\
\hline 6 & Quality Manual of School Z \\
\hline 7 & Institutional website of Partner Organization A (POA) \\
\hline 8 & $\begin{array}{l}\text { The Happy Planet Index: 2012 report - a global index of sustainable well-being } \\
- \text { by POA }\end{array}$ \\
\hline 1 & Institutional website of Partner Organization B (POB) \\
\hline 2 & Strategic Planning 2014/2017 of POB \\
\hline 3 & Who we are and what we do - by POA \\
\hline 4 & Institutional video of POA \\
\hline
\end{tabular}

Source: Authors' work.

\section{MAIN RESULTS AND ANALYSIS}

The course under review - called Economy for Transition - is offered at School $Z$, located in England, United Kingdom. Its program has been developed by this School in association with a British University (referred to in this study as University $Y$ ) and two other NGOs - identified in this work as Partner Organization A (POA) and Partner Organization B (POB).

Initially, there is a brief explanation about School $Z$ and the other organizations that helped in the development of the course. Following that, the main analyses regarding the teaching-learning process, management and change for sustainability in the analyzed case are presented.

\subsection{SCHOOL Z AND PARTNER ORGANIZATIONS}

School Z presents some peculiarities that differentiate it from a traditional El. Its institutional values are 1 ) community - living, working, and learning together; 2) respect for all living systems - an ecological worldview; 3) healthy body - healthy mind. These values guide the activities in the institution. Therefore, all courses are taught in groups with a maximum of 20 participants, focusing on the interaction between classmates, teachers and facilitators of the course. School Z currently has about 20 employees, many of whom are in part-time jobs. The School has employees, students, residents of the various courses, 
volunteer residents, visiting professors, non-resident students, and other visitors. Some of the School professors and staff also reside on campus. It is situated in a small town with 7,500 inhabitants in the southwest of England. Despite being a small new school (only 20 years old) and located in a small municipality, it has stood out and is recognized worldwide for its focus on environmental issues and differentiated teaching methodologies, receiving students from all over the world (SCHOOL Z WEBSITE, 2014).

University $Y$ is also located in southwestern England and has a history dating back to 1862 . It later became a polytechnic school and received university status in 1992 . With more than 26,900 students, it is the 15th largest university in the United Kingdom by total number of students. It also has nearly 2,900 employees making it one of the largest employers in the southwest of England (UNIVERSITY Y WEBSITE, 2014).

The POA - another partner in the Economics for Transition course - is an NGO created in 2006. Its role is to inspire, encourage, connect, support and train communities as they organize themselves around the Transition Model, creating initiatives that rebuild resilience and reduce CO2 emissions (PARTNER ORGANIZATION A WEBSITE, 2014). According to the POA's Strategic Planning 2014/2017, the term "transition" refers to "the changes we need to make to get to a low-carbon, socially just, healthier and happier future, which is more enriching and more gentle on the earth than the way most of us live today." The transition movement is "[...] an ongoing social experiment in which communities learn from each other and is part of a global and historical effort for a better future for ourselves, for future generations and for the planet."

The fourth partner organization of the course under review - POB - is a U.K.-based think tank ${ }^{1}$, which seeks to promote social, economic and environmental justice. It aims to "make a major transition - to transform the economy in a way that works for people and the planet." Its mission is "to relaunch the shift to a new economy through great ideas and a new vision." It proposes to do this through: innovative, high-quality research that shows what is wrong with the current economy and how it can be better; a demonstration of the power of their ideas, putting them into practice; the work with other organizations in the United Kingdom and around the world, to build a movement for economic change (PARTNER ORGANIZATION B WEBSITE).

After this brief explanation of the partner organizations of the course, the main results of the analysis of the teaching-learning process, management and change for sustainability are presented for the case under review.

\subsection{TEACHING-LEARNING}

In relation to the teaching-learning process, as TSLF proposes, the different conceptions of the economic stakeholders are the basic concepts that govern this process. In this sense, several excerpts from the interviews and documents analyzed in the case study point to a broader understanding of the human being. The relation with the concepts of

1. Think tanks are institutions for research, analysis and engagement in public policy. In addition to generating politically oriented research and analysis, they seek to raise awareness in society and decision makers on topics of their interest (ISAPE, 2012) 
Homo sustinens/politicus/ecologicus is made clear in the data, with no data found relating to the narrower view of the self.

It was identified that the course seeks precisely an expansion in relation to the narrow focus of neoclassical economics - as pointed out by Murtaza (2011) as the root of the problems faced by humanity, related to sustainability. In this sense, the co-head of the development of the course emphasizes the basis in ecological thinking, when referring to the first module of the course, which is "rooted in ecology and, thus, is called Ecological Paradigm" and is "deeply rooted in ecological thinking." One of the interviewees explains why this is the first module of the course:

One of the problems of the mass flows of intellectuals [...] of the traditional current, the teaching of orthodox economics, is that they teach nothing about the natural world, so there is no understanding of the dynamics [...] of the natural world. This means that economics is really nothing more than a flow of energy, of materials. [...] Therefore, it seeks to teach people how to understand the economic system, without understanding the natural world, the physical world. It is kind of a half-blind way of attempting to understand the economy. What the course of the School [Z] does is, in the first module, to start with understanding the ecology and then understand economics, and that is exactly the right way to do it, but that is highly unusual (Interviewee 6).

Thus, it is perceived that, contrary to the mainstream view, in which the natural environment is a resource to be explored, in School Z, the environment is understood as a resource for learning. Thus, it helps in the citizens' education process for sustainability.

This fact was also verified in the observations made, in which the natural area surrounding the School's property is highlighted. This provides direct and daily contact with the environment, an important aspect for reconnecting man to nature. This contact is reinforced in lessons given in the midst of nature, demonstrating the importance given to it as a source of learning. In addition, School Z uses production techniques related to organic agriculture and permaculture, involving students in these activities.

The other elements that promote the transformation to sustainability in educational institutions found in the literature regarding the teaching-learning process (Table 1 - first column) were also verified in the case studied, as described below.

The use of strategies focusing on the values proposed by Murtaza (2011) was identified, such as delimited self-interest; good self-esteem; belonging; universal altruism, liberating aesthetics; expropriated exploitation; and unlimited self-realization. One of the teachers of the course points out some of these strategies (such as delimited self-interest, expropriated exploitation, and unlimited self-realization), when talking about how the course can contribute to sustainability:

I believe it occurs in three or four ways. One way, I think, consists of creating agents for change, and get people to demonstrate leadership through integrity. What I mean in some ways is that it is like a training camp where they can become more of themselves. The more integrity people have, the more they are useful in the world. [...] If you have two people saying the same thing, but one person is really saying what is in their heart, in their soul, they will have 
much more power. So part of this is a personal development for realization, [...] what is your its goal and yourits strengths. [...] The second way is, [...] we were talking about, the other day, about the School having a kind of subversive, countercultural way of life. This subversive countercultural way of life means to live in a different way, to live by creating space for more kindness, more cooperation, more compassion and more listening, more affection, more celebration. Thus, we try to create circumstances where these things grow, thus really promoting those parts of people. You know, we all have different mental states. But we can really [...] grow. If we concentrate, we can develop certain mental states. So that is it, to be in the world in a different manner. Then, of course, there is the content of seeing the economy. We can develop different ways of meeting our needs in a different economic system, and show examples of what this looks like in practice, as well as preparing students to be able to create a coherent argument about the shortcomings of the existing system and developing alternatives. So there is, of course, the issue of content in academic terms [...] the development of arguments [...] but also showing in practice what a new economy can really look like. (Interviewee 2)

The liberating aesthetics - which, according to Murtaza (2011), refers to the involvement with the arts and nature, which reduces stress, increases the diversity of life, and facilitates the unleashing of one's inner potential - is also encouraged in School Z. As seen, its facilities are located in an environment surrounded by nature, the contact with it being highly encouraged. Additionally, there are spaces for involvement with the arts, with a craft room in the building, and there are musical instruments available to students, as observed in the visits. Furthermore, in the projects developed by the students for evaluation in the disciplines, there is room for artistic projects to be presented, as shown in the evaluation methods.

The human needs of Max-Neef (1991), addressed by the program, are also related to some of the values brought by Murtaza (2011). Emphasis is given to the question of participation, one of the needs unsatisfied by the current system, according to the coordinator of the Economics for Transition course. In relation to such needs, he states:

They are: subsistence, affection, protection, understanding, participation, leisure, creation, identity, and freedom. That is what we need to be happy. In fact, the societies I was observing in West Africa, in some cases had very little access to money [...] but people were finding ways to meet their needs, because they were more humanized societies. [...] That would be familiar, if you went to the Amazon [...] Citizens of São Paulo, or Porto Alegre, according to the conventional economic model, should be much happier than the people living in the tropical rainforest, because well-being and happiness are measured by GDP, and economic income by purchasing power. [...] However, in fact, the present system is very poor at satisfying many of these needs, in particular the so-called participation, so that we are, in most cases, passive consumers of things that the advertising industry is selling us. For that reason, [...] taking São Paulo or London as examples and taking a look at the suicide rates and the rates of drug abuse and use of antidepressants, this has happened because the major needs are not met. [...] We are living stories in which we are engaging in sensemaking regarding ourselves, trying to inhabit stories that simply are not at the core of who we are as a species. And this opens the gateway to [...] a truly wonderful vision, because it opens the 


\begin{abstract}
door to the possibility that there are ways to meet our innate human needs, by means other than the destructive consumption of Earth. I personally like the fact that I have spent the last 15 years living what we call experimental ecological communities, which were touching these ideas in the search for low-impact ways, not only in physical infrastructure, but also in ways of living and cooperating together. I can say now that, generally, they are happier, they are healthier places [Interviewee 3].
\end{abstract}

The concern with integral formation and the emphasis on values related to self-realization and wisdom seem to be related to the epistemic basis of the School, which is focused on systemic and ecological thinking within a holistic learning model. It has affinity with heterodox economies, which focus on ecocentric organizations and the broader view of being. It is also related to sustainable education, which according to Sterling (2004), is based on the "systemic" rather than the "systematic" - that is, the emphasis is on systemic learning as change, rather than systematic control in response to change.

Thus, it is observed that the teaching-learning process in School Z goes beyond the exclusively cognitive focus - predominant in Els in general - focusing on the learning of the person as a whole. Thus, the side of affection and skills - emphasized by Wals and Jickling (2002) as important in the process of restructuring didactic arrangements for the integration of aspects of sustainability - are also well explored. That is, there is a focus on head, hands and heart, as highlighted by Sipos, Battisti and Grimm (2008), and Singleton (2015). According to Singleton (2015), a holistic framework from the personal perspective of the head, hands and heart is a starting point for modeling the changes in the approach to ecological sustainability and educational reform that offers meaning and purpose to students.

It was possible to find information that makes such position clear in several documents and interviews. As an example, the objectives of the program and key elements of the educational approach of School Z are mentioned, which present such concern:

\begin{abstract}
The main objectives of the program include: [...] acknowledging and developing the whole person as a participant in the co-creation of these transition paths; developing and improving the individual's intellectual/cognitive skills, transferable key competencies, and practical skills for sustainability, work and ecological citizenship [...]. The key elements are: [...] the recognition / development of the whole person - intellectual, emotional, ethical, and practical; to the values of transdisciplinary approaches and different types of knowledge [analytical, sensorial, emotional, sentimental, and intuitive perception]; [...] [SPECIFICATION OF THE ECONOMICS FOR TRANSITION COURSE PROGRAM, 2014].
\end{abstract}

In a complementary way, during the observation process, the use of different teaching methods with different approaches used in the learning process was verified. These range from expository-participatory classes to hands-on lessons and moments of affective development - which reinforces the emphasis on cognitive, affective, and related skills. Examples include interactive workshops; seminars; tutorials and feedback; case studies and field visits; simulations, exercises, dramatization and games; independent study and rea- 
ding; peer-to-peer learning; experiential practice (such as deep ecology exercises); reflective inquiry and reflexive action cycles; and participatory methodologies (such as open spaces).

In compliance with the wide range of teaching-learning methods, the course adopts diversified assessment methods, giving high importance to the feedback process and guaranteeing the process of formative evaluation. This is $100 \%$ work-based, and all modules include the development of a project as one of their evaluation methods. In it, students may choose to submit an academic essay, or a shorter academic essay along with an artistic project or a formal presentation.

The other elements also highlighted by Wals and Jickling (2002), and Palma, Nascimento and Alves (2017) as important in the process of restructuring didactic arrangements for integrating aspects of sustainability - presented in Table 1 - were also found in the case study. There is a strong emphasis on practice and process, as opposed to a focus on content (the latter quite present in traditional universities). Therefore, the partnerships sought with the POA and POB were established with the aim of presenting the students to the new economy in practice.

Collaborative learning is also emphasized. The Quality Manual of School Z emphasizes that all the members who participate in the School, being involved in its learning community, have a responsibility in relation to their learning experience and to that of the others. Thus, School Z is a learning community, where there is a process of constant learning.

Another aspect highlighted by Wals and Jickling (2002), and quite present in this case study, refers to learning with and from outsiders. In this sense, it is observed that the involvement of several stakeholders is part of the strategy and the teaching-learning process of School Z. As stated in the Course Program Specification, "[...] attracting participants, teachers and professionals from across the world" is also one of the key elements of the teaching approach of School Z. The diversity of stakeholders and perspectives, which contributes strongly to the dialogic process, is highlighted in several documents and interviews.

In addition to the several elements already highlighted, the proposal that the students live in the community of the School, participating in its daily activities and rendering services to one another, is also essential in the teaching-learning process of School Z. As the course coordinator points out, "community living is at least fifty percent, if not one hundred percent, of the learning given here."

Thus, in addition to moments for cognitive development (head), students have the time and space to develop other important elements in the teaching-learning process (hands and heart), often neglected by other Els. Therefore, there appears to be an understanding of the importance of creating such spaces for the development of the person as a whole.

For this purpose, the School offers a teaching room dedicated to each of the graduate programs, library, television room, computer room, student rooms for private study, access to the facilities of University $Y$, kitchen area and dining, tea and coffee room, meditation room, handicraft room (with paints, papier-mâché equipment, and other handicraft materials), and a room with musical instruments. Students are free to use these facilities at any time.

This is in line with Wals and Jickling (2002) on the importance of creating spaces (Table 1). According to the authors, such creation of spaces is a result of the search process, rather than a definition of standards for education for sustainability, based on an emancipa- 
tory standpoint, providing an opportunity for the search for more, rather than less, diversity of thought.

Following the analysis of the teaching-learning process, the results of the management process are presented below.

\subsection{MANAGEMENT}

With respect to the management process, the different worldviews behind the organizations (neoclassical, ecological modernization, and ecocentric) are the basic concepts that influence the institution's objectives and the strategic positioning adopted by it, according to the TSLF. In this case study, the ecocentric vision of organizations that predominates in School Z and some partners of the course under analysis, such as the POA and POB, is clear. Such evidence is found in both the documents, the interviewees' statements, and the observations made.

The other elements that promoted the transformation to sustainability in educational institutions found in the literature regarding the management process (Table 1 - second column) were also identified in the case studied.

It should be noted that, in School Z, the economic and social dimensions are considered as incorporated into the environment, which means, according to Kurucz, Colbert and Marcus (2013), that the facets of the triple bottom line (TBL) do not overlap, but are embedded within each other, as concentric circles, with the economy within society, which is within the environment. In this sense, the speech of one of the teachers of the program stands out: "One thing that is really different in the program is that it begins by locating the economy as a subsystem of ecology."

Given the understanding of incorporation in relation to the TBL, the data show that the organizational objectives of School Z go beyond the TBL, considering several second-order issues - integration, reflectivity, equity between generations, transparency and participation (STEURER et al., 2005). As is stated on the website of School Z: "Everything that we do is with the consideration of its impact on the rest of the world."

Related to this is the fact that the program management structure consists of several stakeholders - Programme Coordinator, Programme Administrator and Link Tutor - and commissions - Programmes Committee, Programmes Management Committee, Staff-Student Liaison, Subject Assessment Panel, and Award Assessment Board. This ensures space for the participation of several stakeholders.

Therefore, there is broad space for the participation of both employees, and students and volunteers in decision making. It should be noted that, besides the internal ones, external stakeholders are involved in the processes. In the creation of the course, for example, several stakeholders of different nature were involved, including POA, POB, and University Y.

With regard to the participation of stakeholders, it can still be noted that it also includes the land itself (STEAD; STEAD, 2000). The Student Handbook states: "Together with the abundance of nature, the bio-cultural diversity of the learning group and the community 
in general, it is essential to bring the perspective of what we do here, the actions we decide to take, and the solutions we seek."

The stakeholder approach characterizes a sustainable strategic approach - identified in School Z. This approach assumes that organizations, in addition to bringing gains to investors, should show concern for their stakeholders (BARIN-CRUZ; PEDROZO; ESTIVALETE, 2006; BAUMGARTNER; KORHONEN, 2010). In this sense, the observation made regarding the joint work developed with the community, aimed at improving the environment where School Z is located, is highlighted.

There was also a strong organizational commitment to nature, which is considered not only as a provider of resources. In this case, nature becomes the center of the organization's concerns. Harmony with nature is sought, and resources are seen as finite (STUBBS; COCKLIN, 2008).

In line with the strategic approach adopted by School Z, it is also observed that most of the stakeholders involved in the creation of the program and current partners, such as the POA and POB, understand that organizations should move from an economic-financial logic to a sustainable one. Such partners are based on the conception of ecocentric organizations. An exception is made to University $Y$ which, as a "traditional" university, presents different understandings about the organizations, with the predominance, however, of the traditional neoclassical vision. According to the dean of the Economics for Transition course, these partners were chosen because they are "those who are doing a great job in the conception of a new economy and the transition network. They are the ones who are experimenting and ensuring a highly creative and open space for experimenting with the new world and with what can be the new economy." Thus, the partners are important to the School's learning community.

With regard to the program's management structure, it is found that it is quite flat, with decentralized authority and many of the decisions are taken jointly. There is, as already shown, space for the participation of several stakeholders, requiring constant feedback from all of them.

Additionally, there is a complexification of the decision-making process, since ecology is considered more important than profit, but the school needs to cover its costs. Thus, it considers, in its decision-making, its impact on society, the environment, and the equitable appropriation of results. This is directly related to the incorporated view of the TBL - where the economy is in favor of society and the environment, as opposed to the other way around, as assumed by the mainstream (KURUCZ; COLBERT; MARCUS, 2013), and the sustainable strategic orientation (BARIN-CRUZ; PEDROZO; ESTIVALETE, 2006; BAUMGARTNER; KORHONEN, 2010) identified in School Z. Therefore, the responsibilities are divided among the stakeholders. The daily tasks are shared among all members as part of the learning process:

The day in the organization begins with a community meeting in the morning to survey the activities of the day and allocate work groups and tasks. All students and staff participate in daily cooking, cleaning and gardening activities, as the School understands that this helps to promote a sense of community 
and is a great opportunity for mingling with all members of the institution (SCHOOL Z INSTITUTIONAL WEBSITE, 2014).

Next, we present the results regarding the third process to be analyzed as emerging from the interaction between individuals and the organization.

\subsection{CHANGE FOR SUSTAINABILITY}

The last process to be analyzed refers to the change for sustainability promoted by the course under analysis for sustainability. As a basic concept, according to TSLF, this process envisions sustainability (HOPWOOD; MELLOR; O'BRIEN, 2005; SODERBAUM, 2009). In this sense - corroborating the results related to teaching-learning and management processes - the predominant sustainability vision identified in this case study is related to transformation, which is the main goal of change in the organization. Transformation, as seen, represents the third level of change presented by Waddell (2007), where it is sought to solve problems proactively and seize the opportunities from a perspective of the system as a whole.

The research data show that, for change to take place, the efforts in Case $Z$ are focused on both the socioeconomic issue and the environment. There is a strong emphasis on learning that living in s community and closer proximity to nature can bring about human well-being. Furthermore, two partner organizations of the course - POA and POB - aim to promote the transition and thus focus on socioeconomic issues.

Community living is one of the differentiators presented by School Z. According to the Student Handbook, School Z is "[...] rooted in the place, is inspired by the surroundings and participates, through activities and research, in the local communities to create a more sustainable present and future." Thus, "[...] we begin with a belief in the creativity of the individual, in the power of the community and the wisdom of nature to guide a path of applied hope."

Based on the data analyzed, we can clearly see the emphasis of this case study on local economy and community development based mainly on sustainable agriculture. They state that "the maintenance and operation of the School cannot happen without challenges in terms of sustainability, but our objective is to apply our discourse in daily activities" (SCHOOL Z INSTITUTIONAL WEBSITE, 2014).

Thus, the institution seeks to establish a new philosophy not only in the structures of society, but also in culture. Therefore, they apply in practice the concepts and values in which they believe, being, according to the coordinator of the course, a place where one lives in a "subversive counter-cultural way." Therefore, they seek transformation, understanding their important role in this process. "School $Z$ is not just an academic institution. It is a community where people live, work and come to learn and be part of a larger field of change" (Student Handbook). Thus, they seek to promote the transformation towards sustainability.

In view of the transformation objective, the strategy sought in this case has been the co-creation of a new economy and transformation of the process. Several documents and excerpts from interviews highlight this, including: "We are looking for enthusiastic agents for 
change who are ready to co-create a new economy in practice. We are looking for those who are willing to take the risk and be at the forefront of new thinking in this area." (UNIVERSITY Y INSTITUTIONAL WEBSITE, 2014).

Coherent with such macro-strategy (related to the changes that seek to stimulate society at the macro level), School Z, at the micro level, seeks collaboration (LOZANO, 2008) and transdisciplinarity (ROORDA, 2001).

In this section, it can be concluded that the elements that promote the transformation to sustainability in the Els found in the literature (Table 1) were identified in this case study in the different processes analyzed. Nevertheless, the study also brought as a contribution other elements that are important for the promotion of this transformation. Table 4 highlights the main complementary elements found in the case study.

Table 4 - Complements to the elements promoting the transformation to sustainability in the educational institutions found in the Case Study

\begin{tabular}{l}
\hline - A broader understanding of transformation-related sustainability and the integrated view \\
of the triple bottom line \\
\hline - Community living \\
\hline - Multiple places and times for learning (not restricted to the classroom) - promotion of \\
time and space for Transformative Sustainability Learning (TSL) \\
\hline - Emphasis on various teaching and assessment methods \\
\hline - Use of various feedback mechanisms \\
\hline - Participatory decision-making process \\
\hline - Flat organizational structure, shared responsibility \\
\hline - Encouragement of the dialogical process / involvement of different stakeholders and \\
perspectives in the process \\
\hline - Involvement with nature, with organic agriculture and permaculture \\
\hline - Emphasis on questioning, co-creation and creativity \\
\hline - Stimulus for the creation of alternative forms of organizations \\
\hline - Application of sustainability in practice \\
\hline - Establishment of a network of experiences
\end{tabular}

Source: Author's work based on the research data.

\section{FINAL REMARKS}

This article aimed to identify the elements that promote the transformation for sustainability in Els. For this purpose, those found in the literature related to teaching-learning processes, management and change for sustainability, which are interconnected, were presented initially. Subsequently, a case study was developed in an El that seeks to promote transformative learning for a sustainable life. This, besides confirming the elements found in the literature, complemented them.

The main results found include important changes in the management process and adoption of sustainable strategies and goals that go beyond TBL, involving multiple 
stakeholders. In the teaching-learning process, requirements include the need to expand its focus beyond cognitive objectives, adopting sustainable education and transdisciplinarity as a strategy, as well as the equal involvement of several stakeholders in the process.

Aside from contributing to academic discussions, the results of the study can help courses and universities that seek to implement changes to increase their contribution in promoting sustainability. In particular, it contributes to the discussions on Education for Sustainability that have been broadened in the field of Business Administration (e.g. BRUNSTEIN; GODOY; SILVA, 2014; PALMA; NASCIMENTO; ALVES, 2017), including the creation of tracks on the subject in scientific events such as Enanpad, Engema, and Ecolnovar.

Suggestions for future studies include research in other Els with a focus on sustainability and on Transformative Learning to complement the elements that promote sustainability. In addition, a survey of students in School Z and/or other Els whose teaching proposal aims at sustainability-oriented learning to verify the results of this process may also contribute to discussions in the area.

As a limitation of the study, the results cannot be generalized, particularly with regard to the elements found specifically in the case study, given the peculiarities of the EI studied. Furthermore, the study did not survey the students to ascertain the results of the process, which is intended to be developed in future research. Notwithstanding, the results presented suggest ways for Els to seek, within their context, elements that promote sustainable transformation. As Singleton (2015) puts it, transformative processes are required to shift the prevailing anthropocentric paradigm of Western culture towards more sustainable values and behaviors.

\section{REFERENCES}

BARIN-CRUZ, L.; PEDROZO, E.; ESTIVALETE, V. de F.B. Towards sustainable development strategies: A complex view following the contribution of Edgar Morin. Management Decision, v. 44, n. 7, 871-891, 2006.

BATESON, G. Steps to an Ecology of Mind. San Francisco: Chandler, 1972.

BAUMGARTNER, R.; KORHONEN, J. Strategic Thinking for Sustainable Development. Sustainable Development, v. 18, p. 71-75, 2010.

BECKER, C. The human actor in ecological economics: Philosophical approach and research perspectives. Ecological Economics, v. 60, p.17-23, 2006.

BINA, O.; VAZ, S.G. Humans, environment and economies: From vicious relationships to virtuous responsibility. Ecological Economics, v. 72, p. 170-178, 2011.

BLAKE, J.; STERLING, S.; GOODSON, I. Transformative Learning for a Sustainable Future: An Exploration of Pedagogies for Change at an Alternative College. Sustainability, n. 5, p. 5347-5372, 2013.

BRUNSTEIN, J.; GODOY, A.S.; SILVA, H.C. (orgs.). Educação para Sustentabilidade nas escolas de Administração. São Paulo: RiMa Editora, 2014. 
CARVALHO, S.L.G.; BRUNSTEIN, J.; GODOY, A.S. Um panorama das discussões sobre educação para a sustentabilidade no ensino superior e nos cursos de Administração. In: BRUNSTEIN, J.; GODOY, A.S.; SILVA, H.C. (orgs.). Educação para Sustentabilidade nas escolas de Administração. São Paulo: RiMa Editora, 2014, p. 201-228.

CEULEMANS, K.; DE PRINS, M. Teacher's manual and method for SD integration in curricula. Journal of Cleaner Production, v. 18, p.645-651, 2010.

DEMAJOROVIC, J.; SILVA, H.C.O. da. Formação Interdisciplinar e Sustentabilidade em Cursos de Administração: Desafios e Perspectivas. RAM - Revista de Administração Mackenzie, São Paulo, v. 13, n. 5, p. 39-64, 2012.

FERRER-BALAS, D.; BUCKLAND, H.; MINGO, M. de. Explorations on the University's role in society for sustainable development through a systems transition approach. Case-study of the Technical University of Catalonia (UPC). Journal of Cleaner Production, v. 17, p. 1075-1085, 2009.

FREIRE, P. Pedagogia do Oprimido. Rio de Janeiro: Paz e Terra, 17a. ed. 1987.

GHOSHAL, S. Bad management theories are destroying good management practices. Academy of Management Learning \& Education, v. 4, n.1, p. 75-91, 2005.

HELNE, T; HIRVILAMMI, T. The relational conception of wellbeing as a catalyst for the ecosocial transition. In: MATTHIES, A.; NARHI, K. (orgs.). The Ecosocial Transition of Societies. NY: Routledge, 2017.

HOPWOOD, B.; MELLOR, M.; O'BRIEN, G. Sustainable development: mapping different approaches. Sustainable Development, v. 13, n. 1, p. 38-52, 2005.

KURUCZ, E.C.; COLBERT, B.A.; MARCUS, J. Sustainability as a provocation to rethink management education: Building a progressive educative practice. Management Learning, p. 1-21, 2013.

LOZANO, R. Developing collaborative and sustainable organisations. Journal of Cleaner Production, n. 16, 499-509, 2008.

MARSDEN, R.; TOWNLEY, B.A. A Coruja de Minerva: reflexões sobre a teoria na prática. In: CLEGG, S.R.; HARDY, C.; NORD, W.R. (eds.). Handbook de Estudos Organizacionais, v. 2. São Paulo: Atlas, 2001.

MAX-NEEF, M. Human scale development: conception, application and further reflections. The Apex Press, New York. 1991.

MEZIROW, J. Transformative Learning: Theory to Practice. New Directions for Adult and Continuing Education, n. 74, Summer, 1997.

MORIN, E. O Método 2: a vida da vida. Porto Alegre: Sulina, 2011.

MÜLLER-CHRIST, G. et al. The role of campus, curriculum, and community in higher education for sustainable development - a conference report. Journal of Cleaner Production, v. 62, 2013.

MURTAZA, N. Pursuing self-interest or self-actualization? From capitalism to a steady-state, wisdom economy. Ecological Economics, v. 70, p. 577-584, 2011. 
PALMA, L.C.; PEDROZO, E.A. A Complex Framework: expanding the understanding of the human being and organizations to integrate sustainability in education and promote transformative learning. In: LEAL FILHO, W. (org.). Integrative Approaches to Sustainable Development at University Level: making the links. Frankfurt: Peter Lang Scientific Publishers, 2014, p. 647-662.

PALMA, L.C.; NASCIMENTO, L.F.; ALVES, N.B. (org.). Educação para a sustentabilidade: bases epistemológicas, teorias e exemplos na área de Administração. Canoas, RS: IFRS-Campus Canoas, 2017.

PRUIT, B.; WADDELL, S. Dialogic Approaches to Global Challenges: Moving from "Dialogue Fatigue" to Dialogic Change Processes. A working paper prepared for the generative dialogue project. August 2005. Disponível em: <http://networkingaction.net/wp-content/uploads/ files/GDPWorkingPaper.pdf>. Acesso em: jun 2013.

ROORDA. N. AISHE: Auditing Instrument for Sustainability in Higher Education. Dutch Committee for Sustainable Higher Education, 2001.

SERVA, M.; DIAS, T.; ALPERSTEDT, G.D. Paradigma da Complexidade e Teoria das Organizações: uma reflexão epistemológica. Revista de Administração de Empresas, v. 50, n. 3, 2010.

SIEBENHÜNER, B. Homo sustinens - towards a new conception of humans for the science of sustainability. Ecological Economics, v. 32, p. 15-25, 2000.

SINGLETON, J. Head, Heart and Hands Model for Transformative Learning: place as context for changing sustainability values. Journal of Sustainability Education, v. 9, 2015.

SIPOS, Y.; BATTISTI, B.; GRIMM, K. Achieving transformative sustainability learning: engaging head, hands and heart. International Journal of Sustainability in Higher Education, $v$. 9, n. 1, p. 68-86, 2008.

SODERBAUM, P. Values, ideology and politics in ecological economics. Ecological Economics, v. 28, p.161-170, 1999.

. Making Actors, Paradigms and Ideologies Visible in Governance for Sustainability. Sustainable Development, v. 17, p. 70-81, 2009.

STEAD, J.G.; STEAD, E. Eco-Enterprise Strategy: Standing for Sustainability. Journal of Business Ethics, v. 24, n. 4, p. 313-329, 2000.

STERLING, S. Transformative Learning and Sustainability: sketching the conceptual ground. Learning and Teaching in Higher Education, v. 5, p. 17-32, 2011.

STEURER, R. et al. Corporations, Stakeholders and Sustainable Development I: A Theoretical Exploration of Business-Society Relations. Journal of Business Ethics, v. 61, n. 3, p. 263-281, 2005.

STUBBS, W.; COCKLIN, C. Teaching sustainability to business students: shifting mindsets. International Journal of Sustainability in Higher Education, v. 9, n. 3, p. 206-221, 2008.

WADDELL, S. Realising Global Change: Developing the Tools; Building the Infrastructure. The Journal of Corporate Citizenship, n. 26, 2007. 
WALS, A.E.J.; JICKLING, B. "Sustainability" in higher education: from doublethink and newspeak to critical thinking and meaningful learning. Higher Education Policy, v. 15, p. 121-131, 2002.

WALS, A.E.J.; SCHWARZIN, L. Fostering organizational sustainability through dialogic interaction. The Learning Organization, v. 19, n. 1, p. 11-27, 2012.

WOLLIN, A. Punctuated Equilibrium: Reconciling Theory of Revolutionary and Incremental Change. Systems Research and Behavioral Science, n. 16, p. 359-367, 1999.

YIN, R. Estudo de caso: planejamento e métodos. 2. ed. Porto Alegre: Bookman, 2001.

Submission date: $08 / 04 / 2017$.

Approval date: 18/07/2017. 